\title{
Politieke determinante in die hedendaagse gesprek oor Afrikaans
}

\author{
Marlene Verhoef \\ Departement Tale \\ Potchefstroomse Universiteit vir $\mathrm{CHO}$ \\ Vaaldriehoekkampus \\ VANDERBIJLPARK
}

\begin{abstract}
The influence of political determinants on the recent language debate concerning Afrikaans

Public language debates are identified by issues which have little in common with real language issues but which are determined by political parameters. This article focuses on the particular political determinants which played a major role in the recent language debate concerning Afrikaans. The apparent trends of the debate are interpreted against the background of key concepts such as ideology, hegemony, power and rhetoric and the underlying principles of research paradigms such as Critical Linguistic Study and Language Planning. Subsequently the trends which have become apparent from the media debate as well as the implication of the general direction of this debate are evaluated.
\end{abstract}

\section{Navorsingskonteks}

Periodes van politieke transformasie het deur die loop van die Suid-Afrikaanse geskiedenis nog altyd onsekerheid meegebring. Deur bloot te let op dit wat die afgelope twee eeue ten opsigte van Afrikaans gesê en gedoen is, word dit duidelik dat emosionele handelinge en uitlatings oor taalsake dikwels gelyktydig met ingrypende politieke besluite verloop het. Hierdie gebeure is selfs dikwels in die verlede misbruik as sosiale instrument wat primêr aangewend is om politieke hervorning of teweeg te bring, of te verhinder.

'n Voëlvlug oor die Afrikaanse taalgeskiedenis leer kortliks dat lord Charles Somerset se 1823-taalproklamasie bepaal het dat Engels die enigste administrasietaal van die Kaapkolonie sou wees; lord Milner het aan die begin van die twintigste eeu die openlike anglisering van die hele Surd-Afrika voorgestaan; met die bewindsaanvaarding van die Nasionale Party in 1948 is die openlike bevoordeling van Engels vervang met 'n hegemoniesituasie vir Afrikaans. Hierdie situasie het uiteindelik daartoe bygedra dat swart skoolkinders op 16 Junie 1976 weerstand gebied het teen die oënskynlik gedwonge wyse waarop 
Afrikaans as voertaal op die swart Suid-Afrikaanse skoolgaande bevolking afgedwing is. Uiteindelik het 'n nuwe politieke bedeling in die negentigerjare in Suid-Afrika tot stand gekom. Hoewel die Oorgangsgrondwet (Wet 200 van 1993) konstitusioneel bepaal dat die elf hooftaalgroepe op gelykwaardige vlak amptelike status in Suid-Afrika geniet, dui die huidige taalpraktyk op die ontwikkeling van 'n bevoordelingsituasie vir Engels. ${ }^{1}$

Dit word ook uit die taalgeskiedenis duidelik dat uitlatings oor taalkwessies tydens sodanige politieke oorgangsperiodes dikwels in emosiebelaaide taalgebruik geskied het. Olive Schreiner het tydens die hoogbloei van die periode van Britse Kolonialisme in 1896 gesê: "In fifty years, fight and struggle against it as we wish, there will be no Boer in South Africa speaking the Taal, save as a curiosity, only the great English speaking South African people" (aangehaal deur Steyn, 1980:i). Die middel van die tagtigerjare van die twintigste eeu is enersyds gekenmerk deur 'n nasionale bevrydingstryd en andersyds deur 'n stryd om behoud van die bestaande politieke orde. Hierdie labiele politieke omstandighede het ook in uitlatings oor Afrikaans neerslag gevind: Hein Willemse sê in 1985: “... Afrikaans is inderdaad die taal waarmee ons ons in 'n sosiale, politieke en ekonomiese stryd oproep ... Ek skryf in Afrikaans. Ek stry in Afrikaans" (Willemse, 1985:228-9). Die trant van uitlatings vanuit regse politieke geledere in hierdie selfde tydperk lui: "Afrikaans could become a new symbol to bind whites in South Africa together" (mnr. Louis Stoffberg, HNP-LP in Citizen, 11 Februarie 1986). Die ongeduldigheid binne Afrikanergeledere self oor die stadige hervormingspas in die tagtigerjare in Suid-Afrika word soos volg verwoord met betrekking tot die taalkwessie: "Die wit Boere het Afrikaans te styf aan die hart gedruk en uit skewe liefde hom versmoor" (Rapport, 11 Oktober 1987).

Nadat dit geblyk het dat 'n nuwe politieke bedeling 'n werklikheid in die SuidAfrikaanse samelewing geword het, vind die onsekerheid daarvan ook neerslag in die uitlatings oor Afrikaans: in die periode net voor die vestiging van ' $n$ veelpartydemokrasie in Suid-Afrika sou daar gesê wees dat indien Afrikaans sy amptelike status binne die nuwe politieke bedeling sou verloor, dit tot weerstand binne die wit Afrikanergemeenskap sou leı wat die terreuraktiwiteite van die Ierse

1 Gedurende dic loop van 1995 word dit duidclik dat Engeis dwarsoor dic Suid-Afrikaanse spektrum status wen: Die tocnmalige SAUK bepaal dat Engels voortaan die ankertaal van dic Korporasic sou wees en daar is besluit dat ongevecr $50 \%$ van dic uitsendings in Engels sa! geskied (Beeld, 21 Februarie 1995); dic Suid-Afrikaansc Nasionalc Wecrmag, Kinder- en Gesınsorg en Yskor bepaal dat Engels hicrdie maatskappye se enigste werks- en dokumentasietaal is (kyk onder anderc Beeld, 27 Junic 1995, 1 Desember 1995, 30 Desember 1995). Hoewel die Vrystaatse wetgewer aanvanklik bepaal het dat Afrikaans. Engels en Suid-Sotho die amptelike talc van dic provinsic is. word in besluit gencem dat Engels die enigste dokumentasietaal van die netgewer is (Beeld, 21 April 1995) 
Republikeinse Leèr, die Baske en die African National Congress na cowboy-encrook-speletjies in 'n kleuterskool sou laat lyk (Webb, 1992a:431); 'n briefskrywer aan Rapport, (5 Desember 1993) sê: “Kơn ons sê vir eens en vir altyd: tot hier en nie verder nie! ... Basta met verskonings vra vir die taal ... Kom ons maak vir 'n verandering ons rûe styf, slaan hakke in die grond en sê baie duidelik en ondubbelsinning: Tot hier en nie verder nie!"

Dit word uit die voorafgaande paragrawe duidelik dat die Suid-Afrikaanse politiek in die verlede spesifiek ook in die Afrikaanse taalpolitiek weerklank gevind het. Dit is daarom nie vreemd nie dat die huidige grondwetlike hervormings in Suid-Afrika voorafgegaan is en steeds gevoer word met intensiewe taaldebatte waarin Afrikaans in die fokus staan.

\section{Doel}

Die sentrale doelstelling wat hierdie artikel ten grondslag lê, is om te bepaal watter politieke determinante ' $n$ invloed uitgeoefen het op die Afrikaanse taalgesprek wat die afgelope dekade gevoer is. Dit behoort insiggewend te wees aangesien Afrikaanssprekendes tydens die jongste politieke ontwikkelings 'n totale politieke paradigmaskuif moes deurmaak en die persepsie van hierdie proses sy neerslag gevind het in lede van die spraakgemeenskap se deelname aan die mediagesprek oor Afrikaans. Dit is verder belangrik dat hierdie politieke determinante in die besonder verklaar moet word, aangesien 'n blote beskrywing daarvan geen verhelderende lig sal werp op die makro- en mikrosituasie van Afrikaans in 'n veranderende multitalige bestel nie.

Die spesifieke doel met die afbakening van die betrokke determinante is om te bepaal in watter mate Afrikaans betrokke geraak het in die politieke veranderingsproses en uiteindelike magspel wat hom oor die afgelope dekade in Suid-Afrika voltrek het. Dit word trouens aanvaar dat die transformasieproses in die Suid-Afrikaanse samelewing nie bestudeer kan word sonder om verantwoording te gee van die rol wat taal en taalkwessie daarin gespeel het nie.

Aangesien dit in die besonder gaan om die neerslag van die politieke transformasieproses in die Afrikaanse taalpolitiek, staan die begrippe ideologie, mag, hegemonie en retoriek sentraal en word dit vir hierdie artikel vanuit taalpolitieke hoek geanaliseer en geïnterpreteer. Dit word gedoen sodat daar 'n verklaring gebied kan word vir die sosio-politieke omgewing waarin Afrikaans ingebed is tydens die vestiging van 'n Suid-Afrikaanse veelpartydemokrasie. 


\section{Navorsingsraamwerk}

Volgens Fairclough (1994:5) sluip magsverhoudings in samelewings gewoonlik op onbewustelike wyse by taalsake in en word kwessies soos mag, ideologie en hegemonie dikwels voltrek in taalterme. Daarom noodsaak die kontroverse en emosionele aard van taalkwessies binne veranderende sosio-politieke omstandighede 'n navorsingsparadigma wat van 'n stewige fundamentele en metodologiese onderbou voorsien is. Dit is ook belangrik dat sodanige raamwerk 'n interdissiplinêre aanpak moet hê, aangesien dit gaan om 'n verklaring van die sosio-politieke konteks en die invloed daarvan op die taalkorpus, taalstatus en taalgebruik van 'n sekere taal of tale. Fairclough (1994:6 e.v.) oorweeg verskillende taalkundige modelle waardeur die verhouding tussen taal en mag verklaar kan word, en kom uiteindelik tot die gevolgtrekking dat die gebrek aan 'n interdissiplinêre aanpak in beskikbare taalkundemodelle meebring dat daar nie bevredigend verklaring gebied kan word vir die voorkoms en verklaring van taalgebruik binne sekere sosio-politieke omstandighede nie. Pieterse (1994:8 e.v.) voeg hieraan toe dat die verskillende subdissiplines van die hoofstroomlinguistiek nie ruimte laat vir die verrekening van sosiale veranderlikes in taalgedrag nie.

Die eise van sodanige model is dat die politieke determinante waarbinne taalgebruik in politieke oorgangsperiodes na vore kom, nie eensydig beskou mag word nie en dat taaluitinge en die korrekte interpretasie daarvan nie losgemaak mag word van die sosio-politieke dryfvere waardeur hulle gemotiveer word nie.

Hoewel verskillende teoretiese modelle bruikbare navorsingsraamwerke kan bied, vorm die Critical Linguistic Study (CLS) of die Kritiese Linguistiek wat as kontrabeweging teen die hoofstroomlinguistiek en die Transformasioneel Generatiewe Grammatika ontwikkel het, 'n bruikbare metodologiese onderbou vir die verklaring van die invloed van die omringende sosio-politieke omgewing op taalgebruik (Pieterse, 1994:32; Fairclough, 1994:6-7).

Die hooffokus van die Kritiese Linguistiek is die bepaling en interpretasie van die onlosmaaklike sosiale interafhanklikheid van taal met politieke veranderlikes soos politieke mag, ideologieë en sosiale ongeregtighede wat 'n moontlike invloed mag hê op taalkeuses, taalgebruik en taalgesindhede. Fowler en Kress (1979:185 e.v.) vertolk die konteks waarbinne taaluitinge gemaak word as die wese van die Kritiese Linguistiek. Dit dui daarop dat die onmiddellike konteks van 'n sekere uiting/teks in berekening gebring moet word by die kritiese analise daarvan. Hierdie onmiddellike konteks moet weer gemeet word aan die agtergrond van die breër historiese en sosio-politieke omgewing wat sodanige uiting omring.

Kritiese Linguistiek is in wese begaan oor die invloed van die sosiale, politieke, historiese en ekonomiese omgewing waarbinne 'n taal bestaan en gebruik word 
en die invloed van hierdie sosio-omgewing op die voortbestaansmoontlikhede van 'n taal en sy taalgemeenskap. Daarby gaan dié dissipline op 'n interdissiplinère wyse te werk en word dit beskou as 'n kombinasie van elemente uit die hoofstroomlinguistiek saam met staatsfilosofie, sosiale sielkunde, pragmatiek en diskoersanalise (Pieterse, 1994:33).

Hierdie linguistiese model ondersoek die sterk en deurlopende band wat daar tussen taal- en sosiale strukture bestaan omdat van die veronderstelling uitgegaan word dat die sosiale groeperinge en verhoudinge waarin lede van spraakgemeenskappe staan, 'n invloed op hul taalgedrag moet hê (Fowler \& Kress, 1979:185). Mag- en statusverhoudinge in die sosiale omgewing van spraakgemeenskappe manifesteer dikwels op onbewuste wyse in die taalstrukture van lede van spraakgemeenskappe. Om hierdie rede ondersoek die Kritiese Linguistiek die ewewig tussen taalgedrag en die sosiale omgewing waarin sodanige gedrag manifesteer.

Dit blyk dan dat die Kritiese Linguistiek 'n nuttige navorsingsraamwerk bied vir die bepaling en beoordeling van politieke determinante wat ' $n$ invloed op die posisie van Afrikaans in die jongste grondwetlike ontwikkelings uitgeoefen het. Die waarde van die Kritiese Linguistiek lê hoofsaaklik in die interdissiplinêre fokus op kontensieuse taalkwessies en in die verantwoordbare evalueringsinstrumente wat hierdie teoretiese model bied vir 'n sinvolle interpretasie van die faktore wat direk verbandhou met die taalpolitiek.

Die Kritiese Linguistiek vertoon 'n onlosmaaklike band met taalbeplanning omdat dit beskou kan word as die teoretiese verantwoording van taalbeplanning se situasieanalise-fase. Die waarde van die Kritiese Linguistiek vir die taalbeplanning lê daarin dat dit bruikbare kritiese parameters daarstel waarbinne die inligtingsversameling met die oog op taalbeplanning kan geskied. Hierdie kritiese parameters is in die besonder waardevol omdat méér as net oënskynlike waarnemings gemaak word op grond waarvan taalveranderingsprosesse ontwerp en geïmplementeer moet word en dit stel taalbeplanners ook in staat om die afloop van taalbeplanningsprojekte op wetenskapliker wyse te voorspel. Kortom: die Kritiese Linguistiek sluit in wese by die definisie van taalbeplanning aan, naamlik dat dit as probleemoplossingshandeling doelbewuste taalverandering in die oog het, maar dat die doelwitstelling en proses daarvan gekenmerk moet word deur "'n behoorlike kennisname van die oorsaak en gevolg in die omgewing van sodanige taalprobleme" (Du Plessis, 1989:272).

In teenstelling met Pieterse (1994:33) se standpunt dat die Kritiese Linguistiek meer op mikro-taalstrukture konsentreer, terwyl die taalpolitiek en taalbeplanning implikasies op makro-taalvlak het, word die standpunt hier gehuldig dat die Kritiese Linguistiek inderwaarheid 'n mikro- en makro-vlakaangeleentheid is. In 
wese vertoon taalbeplanning en die Kritiese Linguistiek as teoretiese modelle 'n intersikliese aard en is dit duidelik dat hulle afsonderlik én gesamentlik dieselfde voortgaande taalprosesse binne dinamiese sosiale samelewings fasiliteer en benoem. Die besondere waarde van die twee modelle lê hoofsaaklik in die feit dat dit kontensieuse en hoogs emosionele taalkwessies wat dui op die band tussen taal en gemeenskap in politiek-labiele omstandighede van 'n wetenskaplike onderbou voorsien.

\section{4. 'n Besinning oor en verantwoording van die politieke determinante wat'n rol speel in die gesprek oor Afrikaans}

Die verskyning van J.C. Steyn se boek Tuiste in eie taal (1980) lui 'n tydperk in wat gekenmerk word deur 'n nuwe bewuswording oor die posisie van Afrikaans in Suid-Afrika en waarin die interafhanklike samehang en wedersydse invloede tussen Afrikaans en die sosiale samelewing waarin dit bestaan, die navorsingsfokus ontvang. (Kyk onder andere Prinsloo en Van Rensburg, [1984], Du Plessis \& Du Plessis [1987], Webb [1992b], Du Plessis [1992], Steyn, [1993 en 1995] as werke waarin hierdie verhouding verder ontgin word.)

Dit is opvallend dat sekere teoretiese konsepte dwarsdeur die gepubliseerde werke gebruik word - konsepte wat as politieke merkers geïnterpreteer kan word. Hierdie sleutelbegrippe het implikasies vir die interpretasie van die algemene gees van die Afrikaanse taalgesprek in die politieke oorgangsperiode wat reeds in die vroeë tagtigerjare begin het.

Besondere aandag word in hierdie artikel gegee aan ideologie, hegemonie, mag en retoriek vir sover dit deel vorm en 'n bydrae kan maak tot die gesprek oor taal in die algemeen en tot die besinning oor die posisie van Afrikaans in die besonder.

\subsection{Ideologie}

Cooper (1989:86) voer aan dat die onnadenkende hantering van brandende taalkwessies die potensiaal het om as rookskerm op te tree waardeur een of ander sosiale ongeregtigheid, wat weining met taalsake te make het, uit die weg geruim moet word. Dit het tot gevolg dat taalprobleme sodanig gemanipuleer word dat dit as mobiliseringsimbole in nasionale bevrydings- of bewussynsbewegings optree, hoewel sodanige bewegings en hul doelwitte in wese niks met taal of taalsake te make het nie. Sodanige taalkwessies staan eintlik in diens van die een of ander heersende ideologie en word op só 'n wyse bestuur en op die spits gedryf dat die taalgemeenskap die persepsie het dat hulle, in hulle hantering van die problematiese taalkwessie, 'n gemeenskaplike sosio-politieke doelwit najaag. Fairclough (1994:2) sê duidelik dat ideologie en taal dikwels onlosmaaklik aan 
mekaar verbonde is en dat die neerslag daarvan in taalkwessies dikwels simptomaties is van 'n magstryd wat gewoonlik niks met taal as sodanig te make het nie.

Selfs wat 'n begripsverklaring van ideologie betref, word die standpunt gehuldig dat die begrip sélf geïdeologiseerd geraak het en soveel konnotasies het dat daar selfs van begripsverwarring sprake kan wees (Steyn, 1993:5). Die verskillende konsepte wat aan ideologie geheg word, word soos volg deur Steyn (1993:5 e.v.) verklaar: vanuit die kritiese perspektief dui dit op 'n vooropgesteldheid, oorvereenvoudiging en emosionalisme. Vanuit die positiewe perspektief dui die begrip gewoon op propagandavoertuie wat as't ware as sosiopolitieke handveste alle verbandhoudende optrede sanksioneer. Die neutrale standpunt sien die begrip as sinoniem vir denksisteem.

Vanuit 'n talige konteks kan gesê word dat die begrip ideologie gebruik word om na denkraamwerke te verwys waardeur die werklikheid verstaan word en waardeur vooraf-ervaring georden word (Hodge et al., 1979:81). In die kategorisering en ver-woording van die werklikheid soos dit in denkraamwerke na vore kom, speel taal 'n bepalende rol omdat dit modelle en denkkategorieë daarstel waardeur gemeenskappe hul omgewing verstaan. In wese word denkraamwerke dus sigbaar deur taalgebruik en moet taaluitinge bestudeer word wanneer spesifiek gelet word op die manifestasies van ideologiese prosesse in sosiale gemeenskappe

Ideologiese vooronderstellings het nog altyd bygedra tot die toonaard van die taalgesprek oor Afrikaans (kyk o.a. Steyn, 1980:253, Pokpas \& Van Gensen, 1992:172, Du Plessis, 1992:4). Ook wat die klimaat van die taalgesprek in die post-apartheidsera betref, is dit duidelik dat polities-ideologiese merkers as rigtingwysers in hierdie gesprek optree. Hierdie merkers het nie alleen betrekking op die interne gesprek wat binne die primêre taalgemeenskap gevoer word nie, maar slaan ook op persepsies van lede uit die sekondêre taalgemeenskap en het selfs implikasies vir die volledige multitalige taalbeplanningscenario. Du Plessis (1992:4-5) sê die kem van die probleem met betrekking tot die toekoms van Afrikaans lê in die voorwaarde dat daar heling moet kom ín die Afrikaanse spraakgemeenskap omdat 'n politieke ideologie die natuurlike eenheid tussen Afrikaanssprekendes verwoes het. Die ideologiese geladenheid van die Afrikaanse taalgesprek word andersyds in die besonder onder andere duidelik uit die voormalige SAUK se hantering van die Afrikaanskwessie in April 1995 toe besluit is dat Afrikaans verskuif moet word na 'n derde televisiekanaal wat hoofsaaklik fokus op 'n lae inkomstegroep met 'n lae onderwyspeil (Rapport, 30 April 1995). Daarbenewens bestaan die persepsie dat Afrikaans se toenemende statusverlies in 1994 en 1995 (kyk voetnoot 1) aangevuur kon word deur maatskappye wat politieke gewin wou verkry uit die 
miskenning van Afrikaans omdat dit vertolk sou kon word as 'n gunssoekpoging by die nuwe Suid-Afrikaanse regering (Piet Muller in Rapport, 9 Januarie 1994).

Benewens tipiese sosio-politieke vooroordele moet ook kennis geneem word van die invloed van taalideologiee wat nie as konsep tuishoort in die negatiewe absolutistiese ideësisteem nie, maar eerder dien as neutrale aanduiding van 'n algemeen-aanvaarde denkrigting. Kortliks behels die taalideologieë die volgende (vgl. Cobarnubias,1983:41 e.v.; Reagan, 1986:94 e.v.; Steyn, 1993:7 e.v.):

* Taalassimilasie gaan van die veronderstelling uit dat van individue verwag word om effektief in 'n ander dominante streeks- of nasionale taal te funksioneer as die individu se eerstetaal, ongeag die spreker se persoonlike taalvoorkeur. Dit kom in wese daarop neer dat minderheidstale nie 'n regmatige posisie in 'n pluralistiese samelewing gegee word nie en dat dit ten diepste dui op 'n hiërargiese ordening van tale in 'n multitalige gemeer.skap.

* Taalpluralisme as taalideologie erken 'n veeltalige gemeenskap en gaan van die veronderstelling uit dat middele daargestel moet word om hierdie diversiteit te bewaar en uit te bou. Hierdie uitgangspunt se aanname is dat alle tale as gelykwaardig gesien word en dat gelyke ontwikkelingsgeleenthede aan almal gebied moet word.

* Vernakularisasie word gekenmerk deur die feit dat inheemse tale oor die algemeen amptelike status geniet en dat middele tot die uitbouing en opheffing van sodanige tale daargestel word. Ontwikkelende tale word dus volgens hierdie taalideologiese veronderstelling ontwikkelingsgeleentheid tot amptelikheid gegun.

* Internasionalisasie as taalideologie dui op situasies waar uitheemse tale, gewoonlik van koloniale oorsprong, as amptelike tale gebruik word. Dit bring meestal mee dat minderheidstale nie dieselfde ontwikkelingsgeleentheid geniet as internasionale tale nie.

Dit is opvallend dat bogenoemde taalideologieë in multitalige gemeenskappe 'n tendens tot groepering vertoon: internasionalisasie en assimilasie gaan gewoonlik hand aan hand, terwyl pluralisme en vernakularisasie tegelykertyd die botoon voer. Uit die Suid-Afrikaanse taalgeskiedenis word dit duidelik dat al vier hierdie taalideologiese benaderings in mindere of meerdere mate tegelykertyd 'n bepalende invloed op die bestuur van taalsake uitgeoefen het: in dié mate waarin die veeltalige Suid-Afrikaanse gemeenskap tot 'n tweetalige een gereduseer is, is taalsake hoofsaaklik gerig deur assimilasie en intemasionalisasie. Pluralisme en vernakularisasie as taalideologiese vooronderstellings het tydens die vorige regering se bewind tot gevolg gehad dat korpusbeplanning vir inheemse tale voortgegaan het en dat 'n sekere taalstatus aan hulle verleen is. 
Die kennisname van taalideologieë in onderskeid van sosio-politieke ideologieë is nie alleen waardevol omdat hulle in die besonder ' $n$ invloed uitoefen op die wyse waarop taalbeleide in multitalige samelewings manifesteer nie, maar ook omdat hulle 'n verklaring bied vir die wyse waarop sodanige taalgemeenskappe op mekaar reageer (Steyn, 1993:7). Daarbenewens is daar 'n pertinente band aan te dui tussen taalideologieë en die heersende sosio-politieke ideologieë wat gemeenskappe beïnvloed. ${ }^{2}$

Die onlosmaaklike band tussen sosio-politieke ideologieë en taalsake word verder verklaar in wat Fishman (1968) onderskei as die verskil tussen die bevordering van nasionalisme (Engels: nationalism) en nasionisme (Engels: nationism).

Nasionisme verwys na polities-geografies entiteite wat nie noodwendig dui op homogene sosio-kulturele identiteite nie. Daarteenoor dui nasionalisme op die band wat bestaan tussen lede wat voel dat hulle deur gemeenskaplike geskiedenis, kultuur, godsdiens en taal aan mekaar verbonde is. Hierdie twee verskillende ideologiese uitgangspunte (wat geïnterpreteer word vanuit 'n neutrale konnotasie van die begrip ideologie) bepaal hoedat taalsake in multitalige gemeenskappe bestuur moet word. Taalbehoud, taalversterking en taalverryking wat kodifikasie en uitbreiding insluit, kom aan die orde wanneer dit gaan om die bevordering van nasionalismes. Wanneer dit gaan om die bevordering van nasionisme in 'n multitalige gemeenskap is die uitbou van 'n nasionale taal as kommunikasiemiddel tussen die staatsapparaat en die breë bevolking, die taalmedium in die onderwys en die keuse van 'n taal vir die massakommunikasiemedia tipiese taalprobleme. Akinnaso (1989:142) voer aan dat die keuse van ' $n$ ankertaal binne ' $n$ nasiebouprogram in veeltalige gemeenskappe primêr bepaal word deur dié taal wat allerweě deur die breë bevolking as die effektiefste kommunikasiemedium geïdentifiseer word. ${ }^{3}$

Fishman (1968) se onderskeid tussen die verskillende ideologiese vertrekpunte in multitalige gemeenskappe speel 'n belangrike rol in die korrekte verstaan van

2 Uit die Afrikaanse taalgeskiedenis het dit duidelik geword hoedat assimilasie en die sosiopoliticke idcologie van afsonderlike ontwikkeling met mekaar verband gehou het. In die huidige vroek post-apartheidsera kom dit voor of internasionalisasie (die bevoordeling van Engels ten koste van alle inheemse tale in Suid-Afrika) verband hou met die oenskynlike vestiging van 'n gemecnskaplike Suid-Afrikaanse identiteit.

3 Hierdic mening bied 'n verklaring vir wat tans in dic Suid-Afrikaanse maatskappy aan die gebeur is, naamlik dat slegs Engels as 'n algemene werkstaal gebruik word omdat die persepsie bestaan dat die bree bevolking dit as die effektiefste kommunikasiemedium beskou. Hierdie censydige bevordering van Engels is duidelik ideologies gelaai: nic net word die verset teen Afrikaans en dic vorige politicke bedeling daardeur uitgedruk nic, maar die brec bevolking word die ideaal van internasionale modedinging ten koste van dic eie daardeur voorgchou. 
taalgebruik en retoriek in veranderende sosio-politieke omstandighede en is in die besonder aktueel vir die Suid-Afrikaanse situasie. Hoewel aktıewe pogings tans aangewend word vir die breë vestiging van multıtaligheid (Konsepgrondwet. 1996, PANSAT, 1995; Langtag, 1996) spreek die Suid-Afrikaanse taalpraktyk van 'n oorwegende Engelse eentaligheid. Wanneer hierdie situasie beoordeel word vanuit die nasionalisme/nasionisme-taalideologiese raamwerk, word dit duidelik dat die omstandighede deur ' $\mathrm{n}$ nasionisme-oorweging gerig word.

In die uiterste verklaring word ideologie gesien as 'n ideesisteem wat 'n verabsoluteerde doel najaag wat, as 'n misplaaste kognisie, lei tot 'n skeefgetrokke siening van die waarheid en wat uiteindelik uitloop op 'n verwronge siening van die werklikheid (Smit \& Lubbe, 1990:112). Hierdie valse veronderstelling van die omgewing word later as die enigste aanvaarbare interpretasie van die werklikheid gesien. Uiteindelik lei hierdie verharde, verdraaide en absolute blik op die werklikheid daartoe dat individue en gemeenskappe se uitkyk op die lewe daardeur beheer word. Dit word onder andere uit die volgende aanhaling duidelik dat daar aanduidings uit die afgelope taalgesprek oor Afrikaans bestaan dat hierdie konnotasie van ideologie 'n spesifieke invloed uitgeoefen het op die interpretasie van die taalgespreksklimaat: "Vir die Afrikanervolk beteken dit die aanbreek van 'n nuwe stryd ... 'n Geweldige stryd, want dit gaan niks anders as 'n geweldige stryd wees om onsself in die Nuwe Suid-Afrika ten volle te laat geld nie" (Beeld, 14 Mei 1994).

\subsection{Hegemonie}

Ongeag die feit dat die begrip hegemonie algemeen vertaal word met "leierskap/oorwig/politieke oorheersing" (HAT, 1994; kyk ook Collins, 1990:22), steek daar meer in die begrip.

Benewens politieke oorheersing dui hegemonie ook op die deursuur van 'n spesifieke ideologiese gedagte deur 'n hele gemeenskap totdat 'n heersende sosio-politieke gedagte in alle vorme en in alle lae van die samelewing (die religieuse, die morele, die gewoon sosiale, die intellektuele en die politieke) en binne alle sfere van die werklikheid tot uitdrukking kom.

Hierdie totale neerslag vind ook in taalgebruik en taalkwessies uitdrukking (Pieterse, 1994:46). Sodanige polities-kulturele sanksionering van die hele samelewing op al die vlakke en in alle manifestasievorme het in die besonder verreikende gevolge vir taal en taalkwessies. Die gevolgtrekking kan daarom gemaak word dat, indien 'n taalkwessie na die oppervlak kom, dit in wese maar 'n manifestasievorm is van ánder onderliggende tendense of frustrasies tekenend van die sosio-politiek van die samelewing as 'n geheel. 
Hegemonie en sy stalmaat, ideologie, het deur al die jare 'n beduidende invloed op die Afrikaanse taalsituasie uitgeoefen: die afdwing van 'n monotalıge Engelse beleid het teen die einde van die vorige eeu tot min of meer die helfte van die twintigste eeu gelei tot 'n herlewing van 'n nasionalısme binne die Afrikaanse gemeenskap. Uiteindelik het die hegemonie van Afrikaans, tesame met die persepsie dat dit sonder keuse op 'n multitalige gemeenskap afgedwing is, onder andere gelei tot die bloei van swart nasionalisme in Suid-Afrika. En in die huidige tydsgewrig blyk dit dat die openlike bevoordeling van Engels as die anker- en werkstaal van 'n nuwe politieke bedeling, te midde van 'n veeltalige de jure-situasie, dalk mag dui op taalhegemonie wat, net soos tevore, 'n manifestasie is van ánder heersende sosio-politieke tendense wat daardeur gesanksioneer word. Hierdie feitelike situasie druis in teen die Konsepgrondwet (voorgelê in Mei 1996) waarin Artikels 6(3) en 6(4) bepaal dat meer as een amptelike streekstaal werkstatus op nasionale, provinsiale en plaaslike vlak móét hê. Nie alleen verleen hierdie taalklousules amptelike werkstatus op gelykwaardige en regverdige wyse aan al elf die hooftale in Suid-Afrika nie, maar verwerp dit in beginsel ook die hegemonie van enige enkele taal en daarmee saam ook eentaligheid op regeringsvlak.

\subsection{Mag}

Hoewel dit duidelik gestel moet word dat daar nié 'n een-tot-een korrelasie tussen taal en mag aangetoon kan word nie, is dit duidelik dat 'n onlosmaaklike band tussen hierdie twee sake bestaan. Fairclough (1994:1) sê dat taal en taalgebruik 'n groot rol speel in die totstandkoming, handhawing en verandering van politiessosiale omstandighede wat die gevolg is van 'n magstryd. Ook kom magsverhoudinge voortspruitend uit strydende ideologieë, wat in wese baie min of niks met taal as sodanig te make het nie, baie dikwels na vore in taalkwessies wat op die spits gedryf word.

Die invloed van buitetalige magsverhoudinge op taalsake kan op 'n direkte of verskuilde wyse op makro- en mikro-taalvlakke na vore kom. Op die mikrovlak is woordkeuses en stylaanwending 'n aanduiding van magsverhoudinge, terwyl dit op makrovlak na vore kom in taalbeleidsbesluite waardeur politieke of sosiale mag uitgedruk word. Uiteindelik is dit só dat magsverhoudinge op die makrovlak 'n onafwendbare invloed sal hê op magsverhoudinge op die mikrovlak en ook as sodanig na vore sal kom in die mikroverhoudinge van lede van taalgemeenskappe onderling en op sodanige lede se taalgebruik, woord- en stylkeuses.

Fairclough ( $1994.49 \mathrm{e} \mathrm{v}$.) gaan van die veronderstelling ut dat magsverhoudinge in taalgebruik op 'n direkte of indirekte wyse kan geskied. Magsverhoudinge kom gewoonlik op direkte wyse na vore 11 mondelinge gespreksituasies waar gespreksgenote hul verhouding deur meer as net taalgebruik in stand hou. 
Wanneer magsvertoon op verskulde wyse in taalgebruik na vore kom, geskıed dit gewoonlik by wyse van geskrewe vorm, meestal deur die openbare media waar ' $n$ vooropgestelde idee van wie die leser is en wat sy posisie in hierdie magsverhouding is, bepalende faktore is vir die talige uitdrukking van sodanige verhouding.

Die ter sprake bring van die rol van taal in magsverhoudinge werk verhelderend in op die interpretasie van die invloed van hierdie politieke determinant op die persepsie van die primêre en sekondêre taalgemeenskappe van Afrikaans en sy status. Enersyds word dit duidelik dat die taalgesprek gedetermineer word deur die aanname uit 'n sekere segment van die primêre taalgemeenskap dat Afrikaans se oênskynlike statusverlies gelyklopend met die verlies aan politieke mag deur Afrikaanssprekendes verloop. Theo de Jager (voorsitter van die Junior Rapportryerbeweging) sê in Beeld (16 Junie 1994) dat die statusverlies van Afrikaans in wese gaan om die "aan-die-man-bring" van Afrikaans en Afrikaanssprekendes omdat die persepsie bestaan dat die taal met uitgediende politieke beleidsrigtings in verband gebring word. Andersyds bestaan die indruk dat die gespreksintensiteit juis van só 'n aard is omdat die persepsie onder 'n sekere deel van die primêre taalgemeenskap bestaan dat hul ooglopende toelating van die statusverlies hul instemming met die verlies aan politieke mag sou weergee.

Dit blyk dus dat dit ten diepste gaan om politieke mag en dat Afrikaans die gerieflike kapstok gemaak is van hierdie ambivalente magsverhoudinge. In teenstelling hiermee sê Du Plessis (1992:13) dat die voortbestaan van Afrikaans juis nié van mag afhang nie, maar afhanklik is van positiewe gesindhede.

\subsection{Retoriek}

Alhoewel retoriek en die praktyk van retorika 'n veelfasettige eeue-oue menslike aktiwiteit is, het die begrip mettertyd 'n betekenisverandering ondergaan. Anders as die antieke studiedissiplines van die grammatika en taafilosofie was die retorika nog altyd ten nouste verbonde aan spraakuitinge binne 'n bepaalde kommunikasiesituasie. Dit is duidelik dat die uitwerking van uitsprake op toehoorders en die manipulasie-effek van sodanige uitsprake (hetsy positief of negatief) die wese van die retorika omvat het. Bloomfield en Haugen (1974:xii) dui aan dat retoriek iets gemeen het met die antropologie en kommunikasiepsigologie, omdat al hierdie studievelde in wese begaan is oor die praktiese uitwerking van taal op mense.

Deesdae verwys die begrip retoriek na elegante, dog leë taalgebruik wat nie alleen daarop genig is om mense te beïndruk en oor te haal nie, maar ook om hul tot dade te verbind wat in gewone omstandighede verwerp sou word (Prokhovnik, 1991:1.2): 
At its narrowest, rhetoric refers to speech in which language is used soiely for its persuasive effect upon an audience, regardless of whether or not lis reasoning is sound, and in which language is solely des:gned to pers:tade an audience to undertake a certain course of action

In aansluiting by die voorafgaande definisie word retoriek vir die doeleındes van hierdie artikel verstaan as uitsprake wat in 'n sekere ideologiese substratum ingebed is en wat ' $\mathrm{n}$ band toon met die heersende sosio-politieke omstandighede wat die botoon in die samelewing voer.

Presieser omskryf, word hier verwys na die aanwending van retoriek in die uitsprake oor die posisie van Afrikaans in 'n tydperk van politieke transformasie. Die aanname is dat hierdie politieke verskuiwingsproses tot gevolg het dat die primêre taalgemeenskap hul onsekerheid oor hierdie omstandighede tot uiting bring in ' $n$ taalgesprek aan die hand van taalgebruik wat primêr ter wille van die oorredende effek aangewend is. Wanneer noukeurig gelet word op die woordkeuse van lede van die primère taalgemeenskap in hul uitsprake oor Afrikaans, is dit opvallend dat dit dikwels in vurige en emosiebelaaide taalgebruik geskied wat gelaai is met gevegsmetafore en strydtaal. Die redaksionele kommentaar in Beeld (17 Februarie 1992) waarsku ondere andere nie alleen teen die emosionele toonaard van die taalgesprek nie, maar gebruik sélf gelaaide woorde:

Die taalkwessie is een van die plofbaarste vraagstukke in die land. Mense wat die soeke na 'n nuwe politieke bedeling wil misbruik om te torring aan die posisie van Afrikaans as een van die twee amptelike tale, speel met vuur.

\subsection{Die implikasies van hierdie politieke determinante op Afrikaans}

Die voorafgaande gedeelte het ten doel gehad om kernkonsepte te verklaar wat belangrik is vir ' $n$ gebalanseerde interpretasie en evaluering van die ontwikkelingstendense ten opsigte van die hedendaagse statusbeplanningsgesprek vir Afrikaans. Die implikasies hiervan dui duidelik aan dat die sosio-politieke konteks wat Afrikaans - en trouens alle tale in Suid-Afrika - omring, in bepalende mate verantwoordelik is vir die verloop van die taalgesprek. Om hierdie rede is dit dus van kardinale belang dat sleutelaspekte soos ideologie, hegemonie, magsverhoudinge en retoriek verdiskonteer moet word wanneer situasieanalises gedoen word met die oog op taalbeplanning. Steyn (1980:47 e.v.) dui aan dat 'n taal se toekomsverwagtinge medebepaal word deur propaganda wat vir of téén só 'n taal gemaak word en die tydgees wat kenmerkend is van die onmiddellike omgewing waarin sodanige taal bestaan. Hierdie faktore speel 'n determinerende rol wanneer die taalbeplanningsuitdagings van 'n sekere taal ter sprake kom. 


\section{Gevolgtrekking}

Du Plessis (1992:3) sê: "Die probleme rondom tale en "n regverdige talebestel in Suid-Afrika is nie primêr taalprobleme nie, maar probleme wat gewortel is in die politieke, sosiale of ekonomiese kader."

Die doel met hierdie artikel was juis om die haalbaarheid van só 'n stelling krities te toets aan die teoretiese vooronderstellings van tipiese sosio-politieke determinante én aan die manifestasie daarvan in die taalpraktyk. Ten slotte is dit duidelik dat hierdie determinante méér as blote parameters opgetree het vir die verloop van die gesprek oor Afrikaans. Die politieke geladenheid wat die taal nog altyd gehad het, het feitelik meegebring dat die politieke rigtingswysers, ideologie, hegemonie, mag en retoriek, inderwaarheid as manipuleerders van die taalbeplanningsverloop van Afrikaans opgetree het. Die betekenis hiervan vir die optimalisering van die toekoms van Afrikaans lê daarom juis in 'n behoorlike ontginning en verrekening van die sosio-politiek alvorens daar korpus-, status en taalbemagtigingsbeplanning vir 'n taal gedoen kan word.

\section{Bibliografie}

Akinnaso, F.N. 1989. One nation, four hundred languages: Unity and diversity in Nigeria's language policy Langnage Problems and Ianguage Plamming, 13(2):133-146.

Bloomfield, M. \& Haugen, E. (eds.) 1974. Langiage as a human problem. New York Norton \& Co.

Cobarrubias, J. 1983 Ethical issues in status planning. In: Cobarrubias, J. \& Fishman, J.A. (eds.) Progress in language planning: Imternational perspectives. Berlin : Mouton. p. 41-86.

Collins 1990. Collins pocket reference English dictionary. London : Collins.

Cooper, R.L. 1989. Langrıage planning and social change. Cambridge : Cambridge University Press.

Du Plessis, H. 1989. Die anatomie van taalbeplanning Koers, 54(3):272-289

Du Plessis, H. 1992. En nou Afrikaans? Pretoria : Van Schaik.

Du Plessis, H. \& Du Plessis, T. (reds.) 1987. Afrikaans en taalpolitiek: 15 Opstelle. Pretoria : HAUM.

Fairclough, N. 1994. Langinage and Power. London : Longman.

Fishman, J.A. 1968 . Nationality-nationalism and nation-nationism. In: Fishman, J.A., Ferguson, C.A. \& Das Gupta, J. (eds.) Langiage problems of developing nations New York : John Wiley p. 39-51.

Fowler, R. \& Kress, G. 1979. Critical linguistics. In Fowler, R, Hodge, B., Kress, G., Trew, T (eds.) Language and comtrol. London: Routledge \& Kegan Paul p 185213.

HAT

$k y k$

Odendal, F.F

Hodge. B , Kress, G. \& Jones, G. 1979 The ideology of middle management In Fowler, R. Hodge. B., Kress, G, Trew, T. (eds) Language and control London. Routledge \& Kegan Paui p 81-93 
Langtag

$K y k$

Language Plan Task Group.

Language Plan Task Group. 1996 A language pian for South Africa (Ongepubliseerde aantekeninge.)

Odendal, F.F. (red.) 1994 Verklarende handwordeboek van die Afrikaanse taal Midrand . Perskor.

PANSAT

Kyk

Pan South African Language Board

Pan South African Language Board. 1995 Policy discussion paper. Advanced Draft. Pretoria : Department of Arts, Culture, Science and Technology January 1995 (Gespreksdokument.)

Pieterse, H.J 1994 Taalpolitiek en "Alternatiewe Afrikaans". Pretoria : Unisa. (D.Litt et Phil.-proefskrif.)

Pokpas, L. \& Van Gensen, A 1992. Afrikaans en ideologie in taalbeplanning 'n stryd van standpunte In: Webb, VN. (red) Afrikaans na apartheid Pretoria : Van Schaik p. $165-178$

Prinsloo, K.P \& Van Rensburg, M.C.J. (reds) 1984 Afrikaans: stand, laak en toekoms Pretoria : HAUM.

Prokhovnik, R. 1991. Rhetoric and philosophy in Hobbe's Leviathan New York : Garland Publishing.

Reagan, T.G. 1986. Language ideology in the language planning process: Two African case studies. South African Journal of African Langmages, 6(2) 94-97.

Smit, J.H. \& Lubbe, J.J. 1990. Ideologie en teologie Tydskrif vir Christelike Wetenskap, 27(2):109-138.

Steyn, J.C 1980. Tuiste in eie taal Kaapstad : Tafelberg.

Steyn, J.C. 1993. Taalideologie en taalbeleid in die Suid-Afrikaanse geskiedenis - oorwegings in die ampstaaldebat? Acta Academica, Supplementum 1993: 1

Steyn, J.C. 1995 Die taalstryd in die oorgangstyd Gesindhede teenoor Afrikaans, 1990 1994 Stilet, Supplement 1, April.

Webb, V.N. 1992a. Language attitudes in South Africa: Implications for a post-apartheid democracy. In: Putz, M (ed.) Thirty years of linguisfic evolution. Philadelphia Amsterdam : John Benjamins p. 429-460

Webb, V.N. (red.) 1992b. Afrikaans na apartheid. Pretoria : Van Schaik.

Willemse, H. 1985 Poesie as nie-hegemoniese vorm In: Malan, C \& Smit, B. (reds) Skrywer en gemeenskap p. 227-230 
